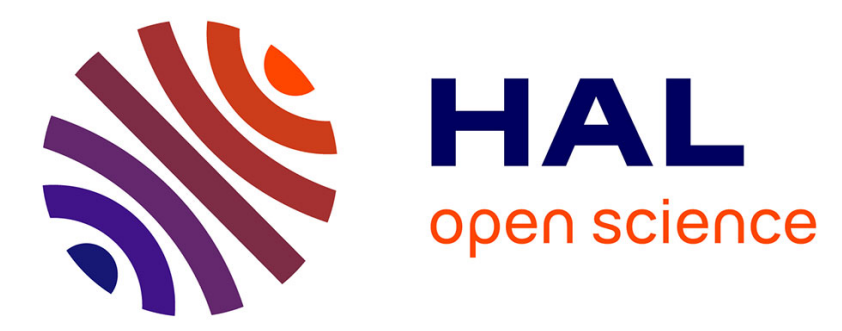

\title{
Scandium and yttrium complexes of an hybrid phenoxy-amidopyridinate ligand. Use in ROP of racemic lactide
}

\author{
J. El Haj Hassan, V. Radkov, V. Dorcet, J.-F. Carpentier, E. Kirillov
}

\section{- To cite this version:}

J. El Haj Hassan, V. Radkov, V. Dorcet, J.-F. Carpentier, E. Kirillov. Scandium and yttrium complexes of an hybrid phenoxy-amidopyridinate ligand. Use in ROP of racemic lactide. Journal of Organometallic Chemistry, 2016, 823, pp.34-39. 10.1016/j.jorganchem.2016.09.014 . hal-01381136

\section{HAL Id: hal-01381136 \\ https://hal-univ-rennes1.archives-ouvertes.fr/hal-01381136}

Submitted on 8 Dec 2016

HAL is a multi-disciplinary open access archive for the deposit and dissemination of scientific research documents, whether they are published or not. The documents may come from teaching and research institutions in France or abroad, or from public or private research centers.
L'archive ouverte pluridisciplinaire HAL, est destinée au dépôt et à la diffusion de documents scientifiques de niveau recherche, publiés ou non, émanant des établissements d'enseignement et de recherche français ou étrangers, des laboratoires publics ou privés. 


\section{For the Table of Contents entry}
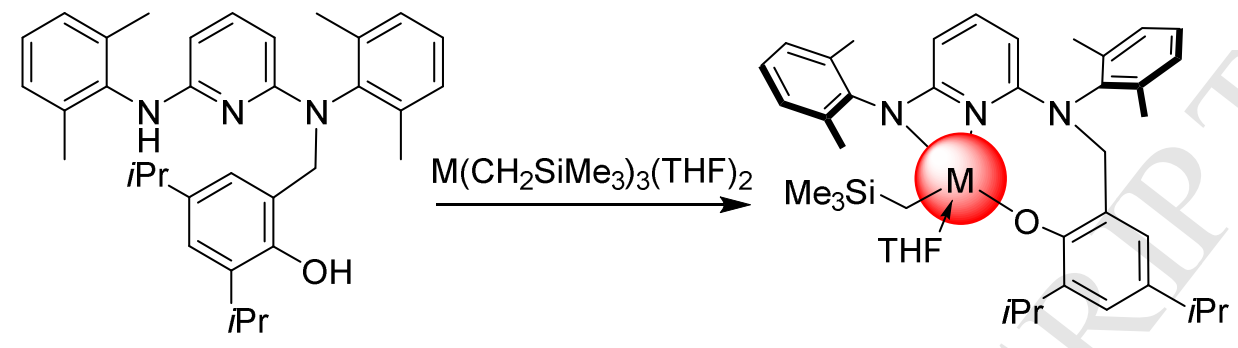

$M=S c, Y$

New alkyl group 3 metal complexes based on a hybrid phenoxy-amidopyridinate ligand have been prepared and used in ROP of racemic lactide.

\section{Highlights}

- Synthesis of the new multidentate hybrid phenol-aminopyridine proligand was developed

- The corresponding alkyl complexes of scandium and yttrium were prepared and characterized

- Alkyl complexes initiate ROP of racemic lactide, alone or in combination with $i \mathrm{PrOH}$, to give atactic PLAs with controlled molecular weights 


\section{Scandium and Yttrium Complexes of an Hybrid Phenoxy-Amidopyridinate Ligand. Use in ROP of Racemic Lactide}

Jad El Haj Hassan, ${ }^{a}$ Vasily Radkov, ${ }^{a}$ Vincent Dorcet, ${ }^{b}$ Jean-François Carpentier ${ }^{a}{ }^{*}$ and Evgueni

$$
\text { Kirillov }^{a^{*}}
$$

${ }^{a}$ Organometallics: Materials and Catalysis, Institut des Sciences Chimiques de Rennes, UMR 6226 CNRS - Université de Rennes 1, Rennes, France

http://www.univ-rennes 1.fr

${ }^{b}$ Centre de Diffractométrie X, Institut des Sciences Chimiques de Rennes, UMR 6226 CNRS Université de Rennes 1, Rennes, France

Abstract. The new multidentate hybrid phenol-aminopyridine proligand $\left\{\mathrm{N}^{\mathrm{Me} 2} \mathrm{NN}^{\mathrm{Me} 2} \mathrm{C}^{i \mathrm{Pr} 2} \mathrm{O}\right\} \mathrm{H}_{2}$ $\left(\mathbf{1}-\mathbf{H}_{2}\right)$ was prepared and used in $\sigma$-bond metathesis reactions with the trialkyl precursors $\mathrm{M}\left(\mathrm{CH}_{2} \mathrm{SiMe}_{3}\right)_{3}(\mathrm{THF})_{2}(\mathrm{M}=\mathrm{Sc}, \mathrm{Y})$. These reactions afforded cleanly the corresponding alkyl complexes $\left\{\mathrm{N}^{\mathrm{Me} 2} \mathrm{NN}^{\mathrm{Me} 2} \mathrm{C}^{\mathrm{iPr} 2} \mathrm{O}\right\} \mathrm{M}\left(\mathrm{CH}_{2} \mathrm{SiMe}_{3}\right)(\mathrm{THF}) \quad(\mathrm{M}=\mathrm{Sc}$ (1-Sc), Y (1-Y)), which were characterized by NMR spectroscopy and microanalysis. Upon crystallization, 1-Sc disproportionates to form the bis(ligand) complex 2-Sc which was isolated and characterized by X-ray crystallography. Complexes 1-Sc and 1-Y were used as initiators in the ring-opening polymerization (ROP) of racemic lactide, alone or in combination with $i \mathrm{PrOH}$, to give atactic PLAs with controlled molecular weights. 


\section{Introduction}

Simultaneous implementation of both phenoxide ${ }^{1}$ and amidinate ${ }^{2}$ anionic ligands into coordination chemistry of early transition metals has engendered evolution of several new classes of polymerization precursors. Group 3 metal complexes with mixed-ligands (Scheme 1, A) have been used as initiators in cyclic esters ring-opening polymerization (ROP) processes, ${ }^{3}$ while their group 4 metal counterparts ${ }^{4}$ have been assessed as olefin (ethylene) polymerization precursors. In more recent studies, incorporation of the two anionic motifs in a single molecular assembly has been successfully achieved, yielding new hybrid chelating dianionic platforms (B and $\mathbf{C})$. For example, Kempe, Kol and coworkers $^{5}$ have reported on amidopyridinate/phenoxy-imino ligand systems (B), which upon coordination onto group 4 metal centers afforded isoselective catalysts for living polymerization of 1hexene. Also, we have described complexes of group 3 and group 4 metals incorporating phenoxyamidinate ligands (C), ${ }^{6}$ which were found competent for initiating ROP of cyclic esters and catalyzing polymerization of ethylene, respectively.

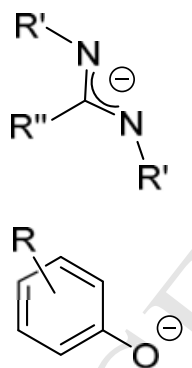

A<smiles>[R]c1cc([R])c([O-])c(/C=N/CCNc2cccc(C)n2)c1</smiles>

B<smiles>[R]N=C(N=O)c1cc(C(C)(C)C)cc(C(C)(C)C)c1[O-]</smiles>

C

Scheme 1. Mixed (A) and hybrid (B, C) phenoxy-amidinate ligand systems used in the development of polymerization catalysts.

In our efforts for developing new discrete catalytic systems for the controlled ROP of cyclic esters via modification/functionalization of dianilinopyridinate-type systems, ${ }^{7}$ we here report a new 
chelating ligand assembly incorporating phenoxide and amidinate anionic moieties. The coordination chemistry of this ligand system with group 3 metals ( $\mathrm{Sc}$ and $\mathrm{Y}$ ) has been investigated, and the activity of the resulting new alkyl complexes was preliminarily assessed in ROP of racemic lactide (rac-LA).

\section{Results and Discussion}

Synthesis of the hybrid phenol-aminopyridine proligand $\left\{\mathrm{N}^{\mathrm{Me} 2} \mathrm{NN}^{\mathrm{Me} 2} \mathrm{C}^{i \mathrm{Pr} 2} \mathrm{O}\right\} \mathrm{H}_{2}\left(1-\mathrm{H}_{2}\right){ }^{8}$ In our previous studies, ${ }^{7}$ we have achieved an efficient and straightforward synthesis of a series of amidine-aminopyridine proligands by the one-step condensation of 2,6-bis(2,6dimethylphenylamino)pyridine with imidoyl chlorides. For the synthesis of proligand $\mathbf{1}-\mathbf{H}_{\mathbf{2}}$, a multistep protocol was used starting from the condensation of 2,6-bis(2-dimethylphenylamino)pyridine with 2-(chlorocarbonyl)-4,6-diisopropylphenyl acetate, followed by reduction and deprotection steps (Scheme 2). $\mathbf{1}-\mathbf{H}_{2}$ was isolated in satisfactory yield as an air-stable solid and characterized by ${ }^{1} \mathrm{H}$ and ${ }^{13} \mathrm{C}$ NMR spectroscopy (see the Supporting Information, Figures S5 and S6, respectively) and combustion analysis.

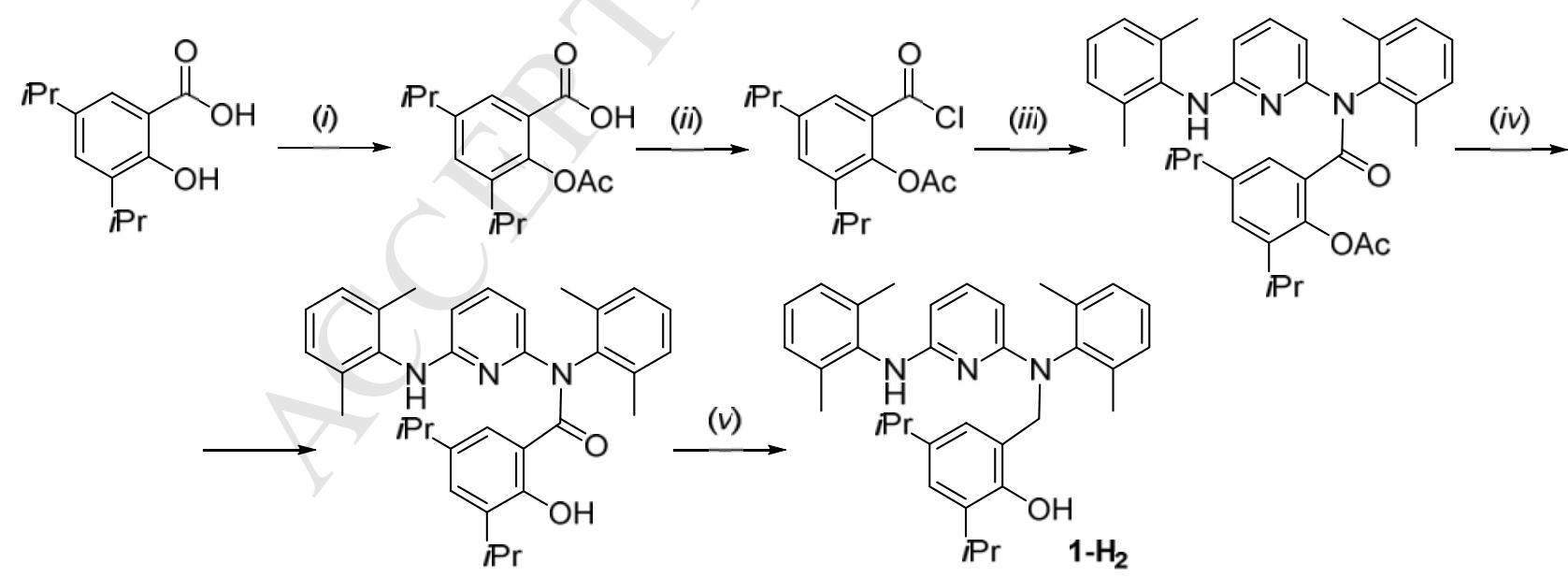

Scheme 2. Synthesis of the hybrid amidine-phenolate proligand $\left[\mathrm{N}^{\mathrm{Me} 2} \mathrm{NN}^{\mathrm{Me} 2} \mathrm{C}^{i \mathrm{Pr} 2} \mathrm{O}\right] \mathrm{H}_{2}\left(\mathbf{1}-\mathbf{H}_{\mathbf{2}}\right)$. Conditions: (i) acetic anhydride (6 equiv), $\mathrm{H}_{2} \mathrm{SO}_{4}$ (cat), $160{ }^{\circ} \mathrm{C}, 15 \mathrm{~min}, 63 \%$ yield; (ii) $\mathrm{SOCl}_{2}(20$ 
equiv), THF, $0{ }^{\circ} \mathrm{C}-\mathrm{RT}$, overnight, $>99 \%$ yield; (iii) $\mathrm{Et}_{3} \mathrm{~N}$ ( 3 equiv), xylenes, $190{ }^{\circ} \mathrm{C}$, overnight, $54 \%$ yield; (iv) $\mathrm{NaOH}(1 \mathrm{M})$, THF- $\mathrm{H}_{2} \mathrm{O}, \mathrm{RT}, 5 \mathrm{~h}, 61 \%$ yield; (v) $\mathrm{BH}_{3} \cdot \mathrm{THF}$ (5 equiv), THF, $0-50{ }^{\circ} \mathrm{C}, 1 \mathrm{~h}$, $30 \%$ yield.

Crystals of $\mathbf{1 - \mathbf { H } _ { 2 }}$ suitable for X-ray diffraction were grown by slow evaporation of a $\mathrm{CHCl}_{3}$ solution in air. Figure 1 shows the molecular structure of $\mathbf{1}-\mathbf{H}_{\mathbf{2}}$, along with selected metrical data.

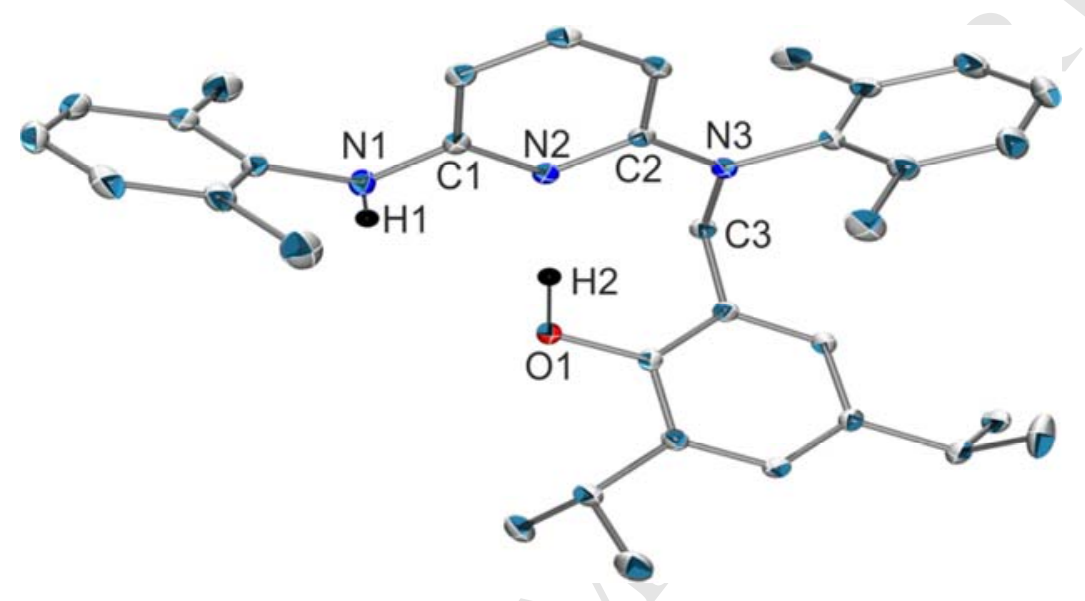

Figure 1. Molecular structure of $\mathbf{1}-\mathbf{H}_{\mathbf{2}}$ (all hydrogen atoms except those of the amidine and phenol moieties are omitted for clarity; thermal ellipsoids drawn at the $50 \%$ probability). Selected bond distances $(\AA)$ and angles $\left(^{\circ}\right)$ : $\mathrm{C}(1)-\mathrm{N}(1), 1.3742(17) ; \mathrm{C}(1)-\mathrm{N}(2), 1.3509(15) ; \mathrm{C}(2)-\mathrm{N}(2), 1.3471(16)$; $\mathrm{C}(2)-\mathrm{N}(3), 1.3768(15) ; \mathrm{N}(1)-\mathrm{H}(1), 0.857 ; \mathrm{O}(1)-\mathrm{H}(2), 0.957 ; \mathrm{N}(2)-\mathrm{H}(2), 1.746$.

Group 3 Metal Alkyl Complexes $\left\{\mathbf{N}^{\mathrm{Me} 2} \mathbf{N N}^{\mathrm{Me} 2} \mathrm{C}^{\mathrm{iPr} 2} \mathrm{O}\right\} \mathrm{M}\left(\mathrm{CH}_{2} \mathrm{SiMe}_{3}\right)(\mathrm{THF})$. Regular $\sigma$-bond metathesis reactions between $\mathbf{1}-\mathbf{H}_{2}$ and trisalkyls $\mathrm{M}\left(\mathrm{CH}_{2} \mathrm{SiMe}_{3}\right)_{3}(\mathrm{THF})_{2}(\mathrm{M}=\mathrm{Sc}$ and $\mathrm{Y})$ were conducted in benzene or in toluene (Scheme 2). In situ monitoring by ${ }^{1} \mathrm{H}$ NMR spectroscopy showed that $\mathrm{M}\left(\mathrm{CH}_{2} \mathrm{SiMe}_{3}\right)_{3}(\mathrm{THF})_{2}$ readily reacts with 1 equiv of proligand at $-30{ }^{\circ} \mathrm{C}$ in toluene- $d_{8}$. Scaling up 
this protocol followed by workup allowed the isolation of analytically pure alkyl THF-adducts 1-Sc and 1-Y in high yields.

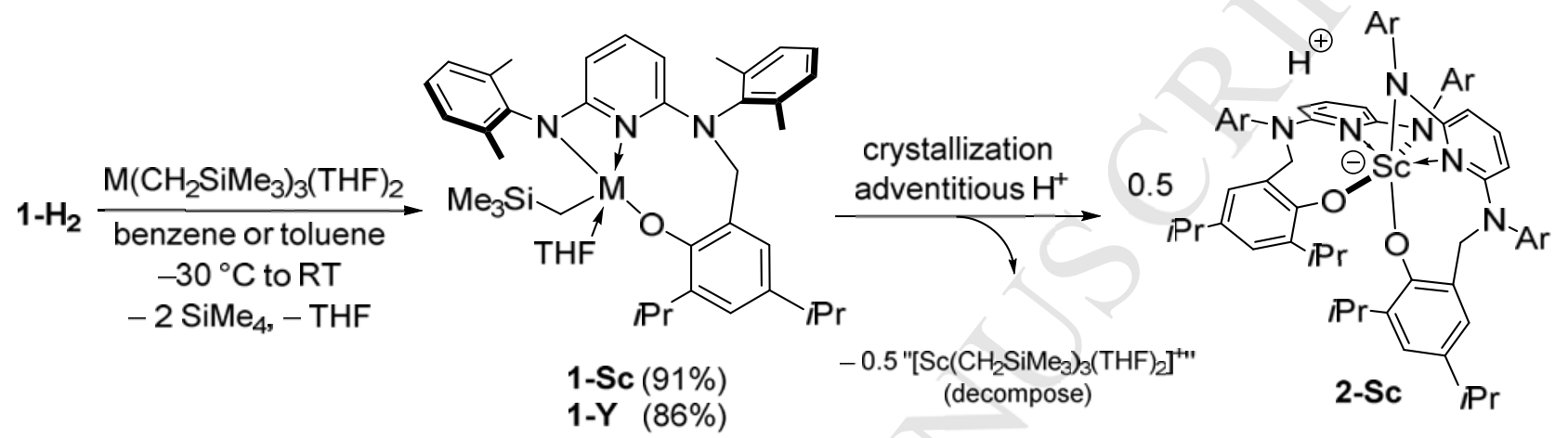

Scheme 2. Synthesis of complexes 1-Sc, 1-Y and isolation of 2-Sc.

The ${ }^{1} \mathrm{H}$ and ${ }^{13} \mathrm{C}\left\{{ }^{1} \mathrm{H}\right\}$ NMR spectra of both 1-Sc and 1-Y display single sets of resonances, consistent with their apparent $C_{1}$-symmetries. For example, the ${ }^{1} \mathrm{H}$ NMR spectrum of 1-Sc (Figure S7; see the SI) exhibits two characteristic doublets $\left(\delta 0.53\right.$ and $\left.0.28 \mathrm{ppm} ;{ }^{2} J_{\mathrm{H}-\mathrm{H}}=11.8 \mathrm{~Hz}\right)$ for the diastereotopic hydrogens of the $\mathrm{CHHSiMe}_{3}$ group. In the ${ }^{1} \mathrm{H}$ NMR spectrum of 1-Y (Figure S10), the same set of signals is found shifted upfield $\left(\delta-0.44\right.$ and $\left.-0.62 \mathrm{ppm} ;{ }^{2} J_{\mathrm{H}-\mathrm{H}}=11.0 \mathrm{~Hz}\right)$. In the ${ }^{13} \mathrm{C}\left\{{ }^{1} \mathrm{H}\right\}$ NMR spectra of 1-Sc and 1-Y (Figures S9 and S11, respectively), the $\mathrm{CH}_{2} \mathrm{SiMe}_{3}$ group appears as one singlet $(\delta 35.9 \mathrm{ppm})$ and one characteristic doublet $\left(\delta 25.9 \mathrm{ppm},{ }^{1} J_{\mathrm{Y}-\mathrm{C}}=41.4 \mathrm{~Hz}\right)$, respectively. Also, the diastereotopic hydrogens of the $\mathrm{CHH}$ linker in the molecules of both compounds appear as two doublets in the corresponding ${ }^{1} \mathrm{H}$ NMR spectra $\left(\delta 6.38\right.$ and $4.32 \mathrm{ppm} ;{ }^{2} J_{\mathrm{H}-\mathrm{H}}=15.1 \mathrm{~Hz}$ and $\delta 5.98$ and $3.98 \mathrm{ppm} ;{ }^{2} J_{\mathrm{H}-\mathrm{H}}=13.7 \mathrm{~Hz}$, respectively). Other aliphatic parts of the ${ }^{1} \mathrm{H}$ NMR spectra for both compounds are quite similar and include three multiplets for each of the $i \operatorname{Pr}$ groups and a series of singlets for the methyl groups of two 2,6-dimethylanilinic units. The aromatic region of the spectra 
features a characteristic pattern of two doublets and one triplet $\left({ }^{3} J_{\mathrm{H}-\mathrm{H}}=8.0 \mathrm{~Hz}\right)$ for the pyridine linker and multiplets for the aniline hydrogens.

All attempts to grow crystals of 1-Sc and 1-Y suitable for X-ray crystallography failed. Both compounds were found stable in aromatic hydrocarbon solutions over several days at room temperature. Nevertheless, ageing a benzene solution of 1-Sc at room temperature over one week afforded crystals of the bis(ligand) product 2-Sc, which apparently resulted from a ligand redistribution reaction. ${ }^{9}$ The molecular solid state structure of complex 2-Sc is shown in Figure 2. The sixcoordinate metal center adopts a geometry that is best described as distorted octahedral with three nitrogen atoms of the two amidinate ligands and one oxygen atom of one phenoxy group in the equatorial plane, and one nitrogen atom (amidinate) and one oxygen of the second phenoxy group in the axial positions, respectively. The metrical parameters (bond lengths and angles) of the two equivalent dianionic ligands are identical suggesting the presence of a proton $\left(\mathrm{H}^{+}\right)$in this presumably zwitterionic structure ${ }^{10}$ however, the latter could not be localized from the X-ray diffraction data. The $\mathrm{Sc}(1)-\mathrm{N}(12)$ and $\mathrm{Sc}(1)-\mathrm{N}(22)(2.258(2) \AA)$ bond distances in 2-Sc are in the regular range (2.183$2.281 \AA$ ) observed in related amidopyridinate-scandium complexes. $^{7 b, c}$ The $\mathrm{Sc}(1)-\mathrm{N}(11)$ and $\mathrm{Sc}(1)-\mathrm{N}(21)(2.331(3) \AA)$ are somewhat longer and can be compared with those $(2.233-2.370 \AA)$ reported for dipyridylamide scandium congeners. ${ }^{11}$ The Sc-O (1.921(2) $\AA$ ) bonds are also in the normal range of those found in scandium complexes of phenoxy-based ligands (1.853-1.969 $\AA) .{ }^{12}$ 


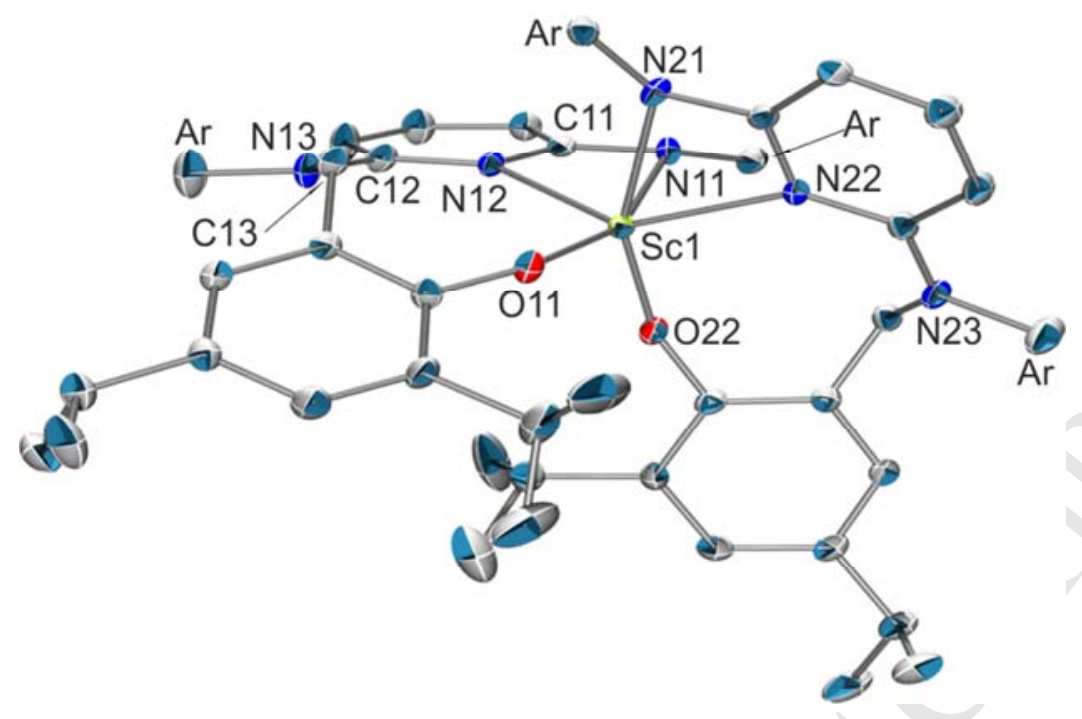

Figure 2. Molecular structure of 2-Sc (all hydrogen atoms and the four 2,6-dimethyl-phenyl groups (Ar) are omitted for clarity; thermal ellipsoids drawn at the $50 \%$ probability). Selected bond distances $(\AA) \quad$ and angles $\quad\left(^{\circ}\right): \quad \mathrm{Sc}(1)-\mathrm{N}(11), \quad 2.331(3) ; \quad \mathrm{Sc}(1)-\mathrm{N}(12), \quad 2.258(2) ; \quad \mathrm{Sc}(1)-\mathrm{O}(11), \quad 1.921(2)$; $\mathrm{Sc}(1)-\mathrm{N}(12), 2.331(3) ; \mathrm{Sc}(1)-\mathrm{N}(22), 2.258(2) ; \mathrm{Sc}(1)-\mathrm{O}(22), 1.921(2) ; \mathrm{C}(11)-\mathrm{N}(11), 1.427(5) ; \mathrm{C}(11)-$ $\mathrm{N}(12), 1.383(6) ; \mathrm{C}(12)-\mathrm{N}(12), 1.360(6) ; \mathrm{C}(12)-\mathrm{N}(13), 1.360(4) ; \mathrm{N}(11)-\mathrm{Sc}(1)-\mathrm{O}(11), 158.50(10) ;$ $\mathrm{N}(12)-\mathrm{Sc}(1)-\mathrm{N}(21), 87.15(10) ; \mathrm{O}(11)-\mathrm{Sc}(1)-\mathrm{O}(22), 99.24(15)$.

Preliminary Studies on Ring-Opening Polymerization of Racemic-Lactide. Alkyl complexes 1-Sc and 1-Y were evaluated as initiators for ROP of rac-lactide (rac-LA) (Scheme 3). In some experiments, $i \mathrm{PrOH}$ was used as a co-initiator. Representative results are summarized in Table 1. 


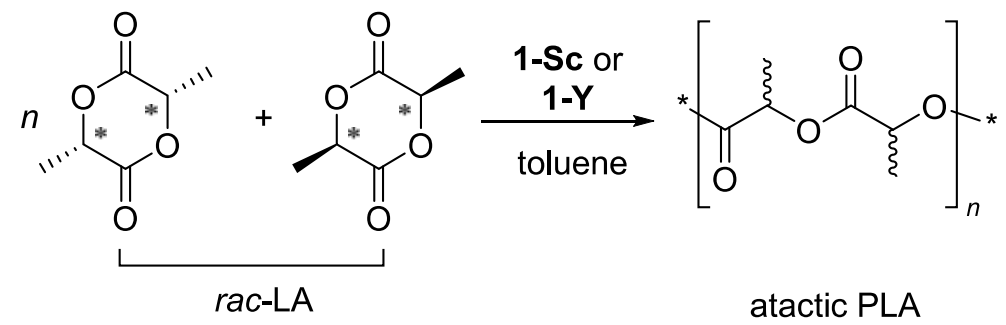

Scheme 3. Ring-opening polymerization of $r a c$-LA.

ROP of rac-LA with 1-Sc and 1-Y proceeded sluggishly in toluene at room temperature (entries 1 and 7, respectively); better performance and control over the molecular weights were achieved upon adding 1 equiv of $i \operatorname{PrOH}$ as a co-initiator. The initiating system 1-Sc/iPrOH (1:1) appeared to be significantly more active at higher temperature $\left(60^{\circ} \mathrm{C}\right)$, enabling high conversion of 100 equiv of rac-LA within 15 min (entry 5). When the same experiment was carried out with 500 equiv, the 1-Sc/iPrOH system showed much lower productivity (entry 6); this probably reflects the high sensitivity of the active scandium species towards minute (protic) impurities contained in the polar monomer. On the other hand, the $1-\mathbf{Y} / \mathrm{iPrOH}$ system proved to be operational at room temperature, and able to withstand monomer loadings up to 500 equiv; introduction of larger amounts of $i \mathrm{PrOH}$ (5 equiv vs. Y) proved, however, detrimental in terms of activity (entries 11 and 12). Sizeexclusion chromatography (SEC) of the polymers produced with both alkyl complexes alone or in the presence of $i \mathrm{PrOH}$ showed monomodal traces with polydispersities $\left(\bigoplus_{\mathrm{M}}\right)$ in the range $1.18-1.58$ (Figure S12). The measured $M_{\mathrm{n}, \mathrm{SEC}}$ and $M_{\mathrm{n}, \mathrm{NMR}}$ values were in general in good agreement with respect to the calculated ones, indicative of essential quantitative initiation. An analysis by ${ }^{1} \mathrm{H}$ NMR spectroscopy of the PLAs produced from 1-Sc and 1-Y revealed the presence of trimethylsilyl resonances (around $\delta 0.00 \mathrm{ppm}, \mathrm{CDCl}_{3}$ ), ${ }^{13}$ consistent with $\mathrm{COCH}_{2} \mathrm{SiMe}_{3}$ end-groups at one terminus of the polymer chain. However, the molecular weights calculated from these resonances were found 
much larger than the theoretical ones, which may be indicative of partial scission of C-Si bonds during the hydrolytic workup. All the PLAs produced in the presence of $i \mathrm{PrOH}$ were shown by NMR spectroscopy to be selectively end-capped with hydroxy- and isopropylcarbonyl groups (Figure S13). The microstructural analysis of the PLA samples obtained with both 1-Sc and 1-Y revealed that they are essentially atactic, with $P_{\mathrm{r}}$ values in the range $0.50-0.56$.

Amidine-amidopyridinate scandium and yttrium bis(trimethylsilylmethyl) analogues of 1-Sc and 1-Y also provided atactic atactic PLAs, but appeared to be somewhat more active ROP initiators. ${ }^{7 \mathrm{~b}}$

Table 1. ROP of $r a c$-LA using complexes 1-Sc and 1-Y. ${ }^{a}$

\begin{tabular}{|c|c|c|c|c|c|c|c|c|c|c|}
\hline Entry & Complex & $\begin{array}{c}{[\mathrm{rac}-\mathrm{LA}]_{0} /} \\
{[\mathrm{M}]_{0} /} \\
{[i \mathrm{PrOH}]_{0}}\end{array}$ & $\begin{array}{c}\mathrm{T} \\
{\left[{ }^{\circ} \mathrm{C}\right]}\end{array}$ & $\begin{array}{l}\text { Time }^{b} \\
{[\mathrm{~min}]}\end{array}$ & $\begin{array}{c}\text { Conv. }^{c} \\
{[\%]}\end{array}$ & $\begin{array}{c}M_{\text {n,theo }}{ } \\
{[\mathrm{g} / \mathrm{mol}]} \\
\left(\times 10^{3}\right)\end{array}$ & $\begin{array}{c}M_{\mathrm{n}, \mathrm{SEC}}{ }^{e} \\
{[\mathrm{~g} / \mathrm{mol}]} \\
\left(\times 10^{3}\right)\end{array}$ & $D_{\mathrm{M}}{ }^{e}$ & $\begin{array}{c}M_{\mathrm{n}, \mathrm{NMR}}{ }^{f} \\
{[\mathrm{~g} / \mathrm{mol}]} \\
\left(\times 10^{3}\right)\end{array}$ & $P_{\mathrm{r}}{ }^{g}$ \\
\hline 1 & 1-Sc & 100:1:0 & 25 & 420 & 4 & nd & nd & nd & nd & nd \\
\hline 2 & 1-Sc & 100:1:0 & 60 & 30 & 29 & 4.18 & nd & nd & nd & nd \\
\hline 3 & $1-S c$ & 100:1:0 & 60 & 90 & 51 & 7.35 & 11.39 & 1.41 & 9.45 & 0.56 \\
\hline 4 & 1-Sc & 100:1:1 & 25 & 960 & 98 & 14.12 & 16.53 & 1.18 & 12.38 & 0.56 \\
\hline 5 & 1-Sc & 100:1:1 & 60 & 15 & 87 & 12.54 & 15.33 & 1.21 & 11.87 & nd \\
\hline 6 & 1-Sc & $500: 1: 1$ & 60 & 90 & 4 & nd & nd & nd & nd & nd \\
\hline 7 & $1-Y$ & 100:1:0 & 25 & 1200 & 65 & 9.37 & 4.54 & 1.32 & 13.1 & 0.50 \\
\hline 8 & $1-Y$ & 500:1:0 & 25 & 60 & 10 & 7.21 & nd & nd & nd & nd \\
\hline 9 & $1-Y$ & 100:1:1 & 25 & 100 & 94 & 13.55 & 15.79 & 1.58 & 12.9 & 0.54 \\
\hline 10 & $1-Y$ & 100:1:1 & 25 & 165 & 92 & 13.26 & 17.63 & 1.46 & 9.26 & 0.54 \\
\hline 11 & $1-Y$ & $500: 1: 1$ & 25 & 60 & 96 & 13.84 & 16.58 & 1.49 & 8.79 & 0.55 \\
\hline 12 & $1-Y$ & $500: 1: 5$ & 25 & 165 & 25 & 3.60 & nd & nd & nd & $\mathrm{nd}$ \\
\hline
\end{tabular}

${ }^{a}$ General conditions: $\left[\mathrm{rac}\right.$-LA] $=1.0 \mathrm{~mol} \cdot \mathrm{L}^{-1}$, toluene. ${ }^{b}$ Reaction times were not optimized. ${ }^{c}$ Conversion of $r a c$-LA was determined by ${ }^{1} \mathrm{H}$ NMR spectroscopy on the crude reaction mixture. ${ }^{d}$ Theoretical $M_{\mathrm{n}}$ values were calculated considering one polymer chain per metal center from the relation: $M_{\mathrm{n} \text {,calc }}=\mathrm{Conv}$. $[\mathrm{LA}] \times[\mathrm{rac}-\mathrm{LA}]_{0} /[\mathrm{M} \text { or } i \mathrm{PrOH}]_{0} \times M_{\mathrm{LA}} \cdot{ }^{e}$ Experimental $M_{\mathrm{n}, \mathrm{SEC}}$ and $\bigoplus_{\mathrm{M}}$ values were determined by GPC in THF $v s$. PS standards and corrected by a factor of $0.58 .{ }^{f}$ Determined by ${ }^{1} \mathrm{H}$ NMR spectroscopy. ${ }^{g} P_{\mathrm{r}}$ is the probability of racemic linkage between monomer units, as determined from the methane region of the homonuclear decoupled ${ }^{1} \mathrm{H}$ NMR spectra.

\section{Conclusions}


The synthesis of a new hybrid phenol-aminopyridine proligand has been developed. Reactions between the proligand $\left[\mathrm{N}^{\mathrm{Me} 2} \mathrm{NN}^{\mathrm{Me} 2} \mathrm{C}^{i \mathrm{Pr} 2} \mathrm{O}\right] \mathrm{H}_{2}\left(\mathbf{1}-\mathrm{H}_{2}\right)$ and $\mathrm{M}\left(\mathrm{CH}_{2} \mathrm{SiMe}_{3}\right)_{3}(\mathrm{THF})_{2}(\mathrm{M}=\mathrm{Sc}$ and $\mathrm{Y})$ afforded selectively the corresponding monoalkyl complexes 1-Sc and 1-Y. Both compounds allowed ROP of rac-lactide under rather mild conditions, providing good control over the polymerization parameters, especially when $i \mathrm{PrOH}$ was used as a co-initiator, but with essentially no stereoselectivity as observed with their bis(trimethylsilylmethyl) analogues incorporating monoanionic amidineamidopyridinate ligand systems. $^{7 b}$ We assume that the lower ROP activity of 1-Sc and 1-Y can be attributed to a larger steric hindrance around the Lewis acidic metal centers coordinated by those bulky dianionic phenoxy-amidopyridinate ligands. Ongoing studies in this field will be focused on further elaboration of new polymerization catalysts incorporating hybrid amidopyridinate-based ligand systems.

\section{Experimental Section}

General Considerations. All reactions, except those for the ligand synthesis were performed under a purified argon atmosphere using standard Schlenk techniques or in a glovebox. Solvents were distilled from $\mathrm{Na}$ /benzophenone (THF, $\mathrm{Et}_{2} \mathrm{O}, \mathrm{DME}$ ) and $\mathrm{Na} / \mathrm{K}$ alloy (toluene, hexane, and pentane) under nitrogen, degassed thoroughly, and stored under nitrogen prior to use. Deuterated solvents (benzene- $d_{6}$, toluene- $d_{8} ;>99.5 \% \mathrm{D}$, Euroisotop) were vacuum-transferred from $\mathrm{Na} / \mathrm{K}$ alloy into storage tubes. $\mathrm{CDCl}_{3}$ and $\mathrm{CD}_{2} \mathrm{Cl}_{2}$ were kept over calcium hydride and vacuum-transferred before use. The precursors bis(dimethylphenylamino)pyridine ${ }^{14}$ and $\operatorname{Ln}\left(\mathrm{CH}_{2} \mathrm{SiMe}_{3}\right)_{3}(\mathrm{THF})_{2}(\mathrm{Ln}=\mathrm{Sc}, \mathrm{Y}){ }^{15}$ were prepared according to literature protocols. Rac-lactide (Aldrich) was recrystallized once from $i \mathrm{PrOH}$ and twice from dry toluene and then dried under vacuum and stored in the glovebox at $-30{ }^{\circ} \mathrm{C}$. Other starting materials were purchased from Acros, Strem, Aldrich, Alfa Aser and used as received. 
Instruments and Measurements. NMR spectra of complexes and ligands were recorded on Bruker AM-400 and AM-500 spectrometers in Teflon-valved NMR tubes at $25{ }^{\circ} \mathrm{C}$, unless otherwise indicated. ${ }^{1} \mathrm{H}$ and ${ }^{13} \mathrm{C}$ chemical shifts are reported in ppm vs SiMe4 $(\delta 0.00)$, as determined by reference to the residual solvent peaks. Assignment of resonances was made from $2 \mathrm{D}{ }^{1} \mathrm{H}^{-}{ }^{1} \mathrm{H}$ COSY, $1 \mathrm{H}^{-13} \mathrm{C}$ HMQC, and HMBC NMR experiments. Coupling constants are given in hertz. The number average molecular masses $\left(M_{\mathrm{n}}\right)$ and polydispersity indexes $\left(\bigoplus_{\mathrm{m}}\right)$ of polymers were calculated with reference to a universal calibration vs. polystyrene standards. The raw $M_{\mathrm{n}, \mathrm{SEC}}$ values of PLAs were corrected with a factor of 0.58 to account for the difference in hydrodynamic volumes between polystyrene and polylactide. ${ }^{16}$ The $M_{\mathrm{n}, \mathrm{NMR}}$ values of PLAs were determined by ${ }^{1} \mathrm{H}$ NMR spectroscopy in $\mathrm{CDCl}_{3}$ on Bruker AM-400 or AC-500 spectrometers. The microstructure of PLAs was determined by homodecoupling ${ }^{1} \mathrm{H}$ NMR spectroscopy at $25{ }^{\circ} \mathrm{C}$ in $\mathrm{CDCl}_{3}$ with a Bruker $\mathrm{AC}-400$ spectrometer operating at $400 \mathrm{MHz}$.

2-Acetoxy-3,5-diisopropylbenzoic acid. 2-Hydroxy-3,5-diisopropylbenzoic acid (25.0 g, 112.4 mmol) and acetic anhydride $(70 \mathrm{~mL}, 674.4 \mathrm{mmol})$ were charged in a $250 \mathrm{~mL}$ two-necked flask equipped with a condenser and a stirring bar. The mixture was heated under reflux at $160{ }^{\circ} \mathrm{C}$ and 10 drops of concentrated $\mathrm{H}_{2} \mathrm{SO}_{4}$ were added; the reaction mixture was refluxed for additional 15 min. The mixture was cooled down to room temperature, mixed with water $(200 \mathrm{~mL})$ and extracted with $\mathrm{CH}_{2} \mathrm{Cl}_{2}(2 \times 50 \mathrm{~mL})$. The organic phases were combined and dried over $\mathrm{Na}_{2} \mathrm{SO}_{4}$, filtered, and the solvent was evaporated under reduced pressure. The resulting oily phase was recrystallized from petroleum ether to afford white-off crystals $(20.7 \mathrm{~g}, 63 \%) .{ }^{1} \mathrm{H}$ NMR $\left(400 \mathrm{MHz}, \mathrm{C}_{6} \mathrm{D}_{6}, 298 \mathrm{~K}\right): \delta 11.52$ (s, $1 \mathrm{H}, \mathrm{COOH}), 7.96\left(\mathrm{~d},{ }^{4} J=2.2,1 \mathrm{H}, \mathrm{Ar}\right), 7.31\left(\mathrm{~d},{ }^{4} J=2.2,1 \mathrm{H}, \mathrm{Ar}\right), 3.17$ (hept, ${ }^{3} J=6.9,1 \mathrm{H}$, $\left.\mathrm{C} H\left(\mathrm{CH}_{3}\right)_{2}\right), 2.62\left(\mathrm{hept},{ }^{3} J=6.9,1 \mathrm{H}, \mathrm{CH}\left(\mathrm{CH}_{3}\right)_{2}\right), 2.09(\mathrm{~s}, 3 \mathrm{H}), 1.16\left(\mathrm{~d},{ }^{3} J=6.9,6 \mathrm{H},\left(\mathrm{CH}_{3}\right)_{2} \mathrm{CH}\right), 1.05$ $\left(\mathrm{d},{ }^{3} \mathrm{~J}=6.9,6 \mathrm{H},\left(\mathrm{CH}_{3}\right)_{2} \mathrm{CH}\right)$. 
2-(Chlorocarbonyl)-4,6-diisopropylphenyl acetate. 2-Acetoxy-3,5-diisopropylbenzoic acid $(5.0 \mathrm{~g}, 18.9 \mathrm{mmol})$ was dissolved in dry THF $(20 \mathrm{~mL})$. Thionyl chloride $(27.4 \mathrm{~mL}, 378 \mathrm{mmol})$ was added slowly at $0{ }^{\circ} \mathrm{C}$ under nitrogen, and the mixture was stirred overnight. Volatiles were removed under vacuum and the resulting dark orange oil was used directly in the next step without further purification. ${ }^{1} \mathrm{H}$ NMR $\left(400 \mathrm{MHz}, \mathrm{C}_{6} \mathrm{D}_{6}, 298 \mathrm{~K}\right): \delta 7.87\left(\mathrm{~d},{ }^{4} J=2.0,1 \mathrm{H}, \mathrm{Ar}\right), 7.27\left(\mathrm{~d},{ }^{4} J=2.0,1 \mathrm{H}, \mathrm{Ar}\right)$, $3.03\left(\mathrm{~m}, 1 \mathrm{H}, \mathrm{CH}\left(\mathrm{CH}_{3}\right)_{2}\right), 2.54\left(\mathrm{~m}, 1 \mathrm{H}, \mathrm{CH}\left(\mathrm{CH}_{3}\right)_{2}\right), 1.98(\mathrm{~s}, 3 \mathrm{H}), 1.07\left(\mathrm{~d},{ }^{3} \mathrm{~J}=6.9,6 \mathrm{H},\left(\mathrm{CH}_{3}\right)_{2} \mathrm{CH}\right), 0.99$ $\left(\mathrm{d},{ }^{3} \mathrm{~J}=6.9,6 \mathrm{H},\left(\mathrm{CH}_{3}\right)_{2} \mathrm{CH}\right)$.

2-(N-(6-(2,6-dimethylphenylamino)pyridin-2-yl)- $N$-(2,6-dimethylphenyl)carbamoyl)-4,6-diisopropylphenyl acetate. To a solution of bis(dimethylphenylamino)pyridine $(4.61 \mathrm{~g}, 14.5 \mathrm{mmol})$ in $o$-xylene $(20 \mathrm{~mL})$ was added $\mathrm{Et}_{3} \mathrm{~N}(6.1 \mathrm{~mL}, 43.6 \mathrm{mmol})$ under argon. A solution of 2(chlorocarbonyl)-4,6-diisopropylphenyl acetate $(18.9 \mathrm{mmol})$ in $o$-xylene $(10 \mathrm{~mL})$ was transferred under argon to the reaction mixture under rigorous stirring. The reaction mixture was refluxed at 190 ${ }^{\circ} \mathrm{C}$ overnight. The solvent was removed under reduced pressure. The resulting black oil was dissolved in $\mathrm{CH}_{2} \mathrm{Cl}_{2}(50 \mathrm{~mL})$ and eluted through an $\mathrm{Al}_{2} \mathrm{O}_{3}$ pad using a 1:1 mixture of $\mathrm{CH}_{2} \mathrm{Cl}_{2}$-heptane as eluent. The eluate was concentrated under vacuum and the product was recrystallized from heptane to afford the desired product as a brownish crystalline material $(4.3 \mathrm{~g}, 52 \%) .{ }^{1} \mathrm{H}$ NMR $\left(400 \mathrm{MHz}, \mathrm{C}_{6} \mathrm{D}_{6}, 298\right.$ $\mathrm{K}): \delta 7.20(\mathrm{~s}, 1 \mathrm{H}, \mathrm{Ar}), 6.93(\mathrm{~m}, 7 \mathrm{H}, \mathrm{Ar}+p-\mathrm{Py}), 6.68$ (br m, 2H, Ar $+m-\mathrm{Py}), 5.71$ (br s, 1H, NH), 5.45 (m, 1H, m-Py), 3.17 (hept, $\left.{ }^{3} J=7.0,1 \mathrm{H}, \mathrm{CH}\left(\mathrm{CH}_{3}\right)_{2}\right), 2.58$ (hept, $\left.{ }^{3} J=7.0,1 \mathrm{H}, \mathrm{CH}\left(\mathrm{CH}_{3}\right)_{2}\right), 2.44$ (s, 3H, $\left.\mathrm{CH}_{3} \mathrm{C}(\mathrm{O})\right), 2.04\left(\mathrm{~s}, 6 \mathrm{H},\left(\mathrm{CH}_{3}\right)_{2} \mathrm{C}_{6} \mathrm{H}_{3} \mathrm{~N}\right), 1.89\left(\mathrm{~s}, 6 \mathrm{H},\left(\mathrm{CH}_{3}\right)_{2} \mathrm{C}_{6} \mathrm{H}_{3} \mathrm{~N}\right), 1.19\left(\mathrm{~d},{ }^{3} \mathrm{~J}=7.0,6 \mathrm{H},(\mathrm{CH})_{2} \mathrm{CH}\right)$, $1.00\left(\mathrm{~d},{ }^{3} \mathrm{~J}=6.9,6 \mathrm{H},\left(\mathrm{CH}_{3}\right)_{2} \mathrm{CH}\right)$.

\section{$N$-(6-(2,6-dimethylphenylamino)pyridin-2-yl)-2-hydroxy-3,5-diisopropyl- $N$-(2,6-} mixture of $\mathrm{MeOH}(50 \mathrm{~mL})$ and THF $(70 \mathrm{~mL})$. A $1 \mathrm{M} \mathrm{NaOH}$ solution $(90 \mathrm{~mL})$ was added dropwise at 
room temperature and progress of the reaction was monitored by TLC. After $5 \mathrm{~h}, \mathrm{CH}_{2} \mathrm{Cl}_{2}(100 \mathrm{~mL})$ was added and the organic phase was extracted with water $(2 \times 200 \mathrm{~mL})$. The organic phases were combined, dried over $\mathrm{Na}_{2} \mathrm{SO}_{4}$ and then filtrated. The resulting solution was passed through a short pad of silica. Volatiles were evaporated and the white residue was dried to give the desired pure product (2.40 g, 61\%). ${ }^{1} \mathrm{H}$ NMR (400 MHz, $\left.\mathrm{C}_{6} \mathrm{D}_{6}, 298 \mathrm{~K}\right): \delta 11.84$ (s, 1H, OH), 7.1 (s, 1H, Ar), 6.94 (m, 7H, Ar), 6.77 (br t $,{ }^{3} J=7.0,1 \mathrm{H}, p$-Py), 6.26 (br m, 1H, $m$-Py), 5.51 (d, ${ }^{4} J=7.0,1 \mathrm{H}, m$-Py), 5.18 (s, $1 \mathrm{H}$, $\mathrm{NH}$ ), 3.67 (hept, $\left.{ }^{3} \mathrm{~J}=6.9,1 \mathrm{H}, \mathrm{CH}\left(\mathrm{CH}_{3}\right)_{2}\right), 2.57$ (hept, $\left.{ }^{3} \mathrm{~J}=6.9,1 \mathrm{H}, \mathrm{CH}\left(\mathrm{CH}_{3}\right)_{2}\right), 2.26$ (s, 6H, $\left.\left(\mathrm{CH}_{3}\right)_{2} \mathrm{C}_{6} \mathrm{H}_{3} \mathrm{~N}\right), 1.86\left(\mathrm{~s}, 6 \mathrm{H},\left(\mathrm{CH}_{3}\right)_{2} \mathrm{C}_{6} \mathrm{H}_{3} \mathrm{~N}\right), 1.32\left(\mathrm{~d},{ }^{3} \mathrm{~J}=6.9,6 \mathrm{H},\left(\mathrm{CH}_{3}\right)_{2} \mathrm{CH}\right), 1.01\left(\mathrm{~d},{ }^{3} \mathrm{~J}=6.9,6 \mathrm{H}\right.$, $\left.\left(\mathrm{CH}_{3}\right)_{2} \mathrm{CH}\right)$.

Proligand $\left\{\mathbf{N}^{\mathrm{Me} 2} \mathbf{N N} \mathbf{N e}^{\mathrm{Me} 2} \mathbf{C}^{i \mathbf{P r 2}} \mathbf{O}\right\} \mathbf{H}_{2} \quad\left(\mathbf{1 - H _ { 2 } ) .} \quad\right.$ In a Schlenk flask, $\quad N-(6-(2,6-$ dimethylphenylamino)pyridin-2-yl)-2-hydroxy-3,5-diisopropyl- $N$-(2,6-dimethylphenyl)benzamide $(2.2 \mathrm{~g}, 4.217 \mathrm{mmol})$ was dissolved in dry THF $(15 \mathrm{~mL})$ under argon atmosphere. $\mathrm{BH}_{3} \cdot \mathrm{THF}(21.0 \mathrm{~mL}$ of a $1 \mathrm{M}$ solution in THF, $21.0 \mathrm{mmol}$ ) was added dropwise at $0{ }^{\circ} \mathrm{C}$. The reaction mixture was stirred at $50{ }^{\circ} \mathrm{C}$ for $1 \mathrm{~h}$, then cooled down to room temperature and quenched by addition of a $10 \% \mathrm{NH}_{4} \mathrm{Cl}$ solution $(10 \mathrm{~mL})$. Volatiles were evaporated and the solid residue was dissolved in $\mathrm{CH}_{2} \mathrm{Cl}_{2}(50 \mathrm{~mL})$. The resulting solution was passed through a short pad of silica, the solution was concentrated under vacuum and the white residue was recrystallized from methanol to afford the desired proligand as an analytically pure white powder $(0.63 \mathrm{~g}, 30 \%) .{ }^{1} \mathrm{H} \mathrm{NMR}\left(400 \mathrm{MHz}, \mathrm{C}_{6} \mathrm{D}_{6}, 298 \mathrm{~K}\right): \delta 12.27(\mathrm{~s}, 1 \mathrm{H}$, $\mathrm{OH}), 7.21\left(\mathrm{~d},{ }^{4} \mathrm{~J}=2.1,1 \mathrm{H}, \mathrm{Ar}\right), 6.97(\mathrm{~m}, 6 \mathrm{H}, \mathrm{Ar}) 6.72\left(\mathrm{t},{ }^{3} J=7.0,1 \mathrm{H}, p-\mathrm{Py}\right), 6.47\left(\mathrm{~d},{ }^{4} J=2.1,1 \mathrm{H}, \mathrm{Ar}\right)$, $5.96(\mathrm{~s}, 1 \mathrm{H}, \mathrm{NH}), 5.28\left(\mathrm{~d},{ }^{3} J=7.0,2 \mathrm{H}, m-\mathrm{Py}\right), 4.89\left(\right.$ br s, $\left.2 \mathrm{H}, \mathrm{CH}_{2}\right), 3.86\left(\right.$ hept $,{ }^{3} J=6.9,1 \mathrm{H}$, $\left.\mathrm{CH}\left(\mathrm{CH}_{3}\right)_{2}\right), 2.69$ (hept, $\left.{ }^{3} \mathrm{~J}=6.9,1 \mathrm{H}, \mathrm{CH}\left(\mathrm{CH}_{3}\right)_{2}\right), 2.17\left(\mathrm{~s}, 6 \mathrm{H},\left(\mathrm{CH}_{3}\right)_{2} \mathrm{C}_{6} \mathrm{H}_{3} \mathrm{~N}\right), 1.78(\mathrm{~s}, 6 \mathrm{H}$, $\left.\left(\mathrm{CH}_{3}\right)_{2} \mathrm{C}_{6} \mathrm{H}_{3} \mathrm{~N}\right), 1.49\left(\mathrm{~d},{ }^{3} \mathrm{~J}=6.9,6 \mathrm{H},\left(\mathrm{CH}_{3}\right)_{2} \mathrm{CH}\right), 1.15\left(\mathrm{~d},{ }^{3} \mathrm{~J}=6.9,6 \mathrm{H},(\mathrm{CH})_{2} \mathrm{CH}\right) .{ }^{13} \mathrm{C}\left\{{ }^{1} \mathrm{H}\right\} \mathrm{NMR}$

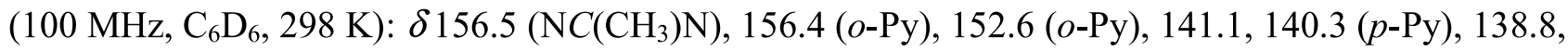
$137.7,136.7,136.5,136.2,129.0,128.3,128.3,127.6,126.8,126.6,124.2,123.4,96.9$ (m-Ру), 93.3 
(m-Py), $50.6\left(\mathrm{CH}_{2}\right), 33.6\left(\mathrm{CH}\left(\mathrm{CH}_{3}\right)_{2}\right), 28.0\left(\mathrm{CH}\left(\mathrm{CH}_{3}\right)_{2}\right), 24.2\left(\mathrm{CH}\left(\mathrm{CH}_{3}\right)_{2}\right), 22.8\left(\mathrm{CH}\left(\mathrm{CH}_{3}\right)_{2}\right), 18.0$ $\left(\mathrm{NC}\left(\mathrm{CH}_{3}\right) \mathrm{N}\right), 17.7\left(\left(\mathrm{CH}_{3}\right)_{2} \mathrm{C}_{6} \mathrm{H}_{3} \mathrm{~N}\right)$. Anal. Calcd for $\mathrm{C}_{34} \mathrm{H}_{41} \mathrm{~N}_{3} \mathrm{O}: \mathrm{C}, 80.43 ; \mathrm{H}, 8.14 ; \mathrm{N}, 8.28$. Found: C, $80.55 ; \mathrm{H}, 8.27 ; \mathrm{N}, 8.85$.

$\left\{\mathbf{N}^{\mathrm{Me} 2} \mathbf{N N}^{\mathrm{Me} 2} \mathbf{C}^{\mathrm{iPr} 2} \mathbf{O}\right\} \mathbf{S c}\left(\mathrm{CH}_{2} \mathrm{SiMe}_{3}\right)(\mathbf{T H F})$ (1-Sc). To a solution of 1-H $(300 \mathrm{mg}, 0.591 \mathrm{mmol})$ in toluene $(5 \mathrm{~mL})$ was added a solution of $\mathrm{Sc}\left(\mathrm{CH}_{2} \mathrm{SiMe}_{3}\right)_{3}(\mathrm{THF})_{2}(266.4 \mathrm{mg}, 0.591 \mathrm{mmol})$ in toluene $(5 \mathrm{~mL})$ at $-30{ }^{\circ} \mathrm{C}$. The reaction mixture was stirred overnight at room temperature. Volatiles were evaporated under vacuum and the crude solid residue was dried overnight, washed with hexane (10 $\mathrm{mL}$ ), to afford the desired product as white-yellow powder of 1-Sc $(382 \mathrm{mg}, 91 \%) .{ }^{1} \mathrm{H}$ NMR (400 $\left.\mathrm{MHz}, \mathrm{C}_{6} \mathrm{D}_{6}, 298 \mathrm{~K}\right): \delta 7.20-6.80(\mathrm{~m}, 7 \mathrm{H}, \mathrm{Ar}), 6.70\left(\mathrm{t},{ }^{3} J=8.1,1 \mathrm{H}, p-\mathrm{Py}\right), 6.52\left(\mathrm{~d},{ }^{4} J=2.3,1 \mathrm{H}, \mathrm{Ar}\right)$, $6.38\left(\mathrm{~d},{ }^{2} J=15.1,1 \mathrm{H}, \mathrm{CHH}\right), 5.07\left(\mathrm{~d},{ }^{3} J=8.0,1 \mathrm{H}, m-\mathrm{Py}\right), 5.02\left(\mathrm{~d},{ }^{3} J=8.0,1 \mathrm{H}, m-\mathrm{Py}\right), 4.32\left(\mathrm{~d},{ }^{2} J=\right.$ 15.1, 1H, CHH), 3.85 (br m, 4H, THF), 3.62 (hept, $\left.{ }^{3} J=7.0,1 \mathrm{H}, \mathrm{C} H\left(\mathrm{CH}_{3}\right)_{2}\right), 2.73$ (hept, ${ }^{3} J=7.0,1 \mathrm{H}$, $\left.\mathrm{CH}\left(\mathrm{CH}_{3}\right)_{2}\right), 2.48\left(\mathrm{~s}, 3 \mathrm{H},\left(\mathrm{CH}_{3}\right)_{2} \mathrm{C}_{6} \mathrm{H}_{3} \mathrm{~N}\right), 2.26\left(\mathrm{~s}, 3 \mathrm{H},\left(\mathrm{CH}_{3}\right)_{2} \mathrm{C}_{6} \mathrm{H}_{3} \mathrm{~N}\right), 2.04\left(\mathrm{~s}, 3 \mathrm{H},\left(\mathrm{CH}_{3}\right)_{2} \mathrm{C}_{6} \mathrm{H}_{3} \mathrm{~N}\right), 1.64$ $\left(\mathrm{s}, 3 \mathrm{H},\left(\mathrm{CH}_{3}\right)_{2} \mathrm{C}_{6} \mathrm{H}_{3} \mathrm{~N}\right), 1.49\left(\mathrm{~m}, 6 \mathrm{H},(\mathrm{CH})_{2} \mathrm{CH}\right), 1.18\left(\mathrm{~d},{ }^{3} \mathrm{~J}=6.9,3 \mathrm{H},(\mathrm{CH})_{2} \mathrm{CH}\right), 1.15\left(\mathrm{~d},{ }^{3} J=7.0\right.$, $\left.3 \mathrm{H},\left(\mathrm{CH}_{3}\right)_{2} \mathrm{CH}\right), 1.08$ (br m, 4H, THF), $0.53\left(\mathrm{~d},{ }^{2} J=11.8,1 \mathrm{H}, \mathrm{CHHSiMe}\right.$ ), 0.31 (s, 9H, SiMe $), 0.28$

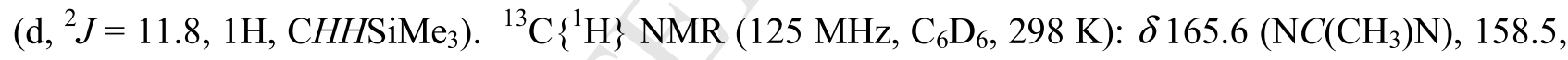
155.1, 146.2, 141.9 (p-Рy), 141.5, 139.0, 136.5, 135.1, 134.2, 133.1, 129.5, 128.7, 126.7, 126.5, 123.5, 123.2, 93.1 (m-Py), 91.2 (m-Py), $68.8\left(\alpha-\mathrm{CH}_{2} \mathrm{THF}\right), 51.6\left(\mathrm{CH}_{2}\right), 35.9\left(\mathrm{CH}_{2} \mathrm{SiMe}_{3}\right), 33.6\left(\mathrm{CH}\left(\mathrm{CH}_{3}\right)_{2}\right)$, $27.5\left(\mathrm{CH}\left(\mathrm{CH}_{3}\right)_{2}\right), 25.1\left(\beta-\mathrm{CH}_{2} \mathrm{THF}\right), 24.4\left(\mathrm{CH}\left(\mathrm{CH}_{3}\right)_{2}\right), 23.9\left(\mathrm{CH}\left(\mathrm{CH}_{3}\right)_{2}\right), 23.1\left(\mathrm{CH}\left(\mathrm{CH}_{3}\right)_{2}\right), 22.8$ $\left(\mathrm{CH}\left(\mathrm{CH}_{3}\right)_{2}\right), 18.9\left(\left(\mathrm{CH}_{3}\right)_{2} \mathrm{C}_{6} \mathrm{H}_{3} \mathrm{~N}\right), 18.3\left(\left(\mathrm{CH}_{3}\right)_{2} \mathrm{C}_{6} \mathrm{H}_{3} \mathrm{~N}\right), 18.2\left(\left(\mathrm{CH}_{3}\right)_{2} \mathrm{C}_{6} \mathrm{H}_{3} \mathrm{~N}\right), 17.8\left(\left(\mathrm{CH}_{3}\right)_{2} \mathrm{C}_{6} \mathrm{H}_{3} \mathrm{~N}\right), 3.6$ (SiMe $)$. Anal. Calcd for $\mathrm{C}_{42} \mathrm{H}_{58} \mathrm{~N}_{3} \mathrm{O}_{2} \mathrm{ScSi}: \mathrm{C}, 71.05 ; \mathrm{H}, 8.23 ; \mathrm{N}, 5.92$. Found: $\mathrm{C}, 71.70 ; \mathrm{H}, 8.64 ; \mathrm{N}$, 6.05 .

$\left\{\mathbf{N}^{\mathrm{Me} 2} \mathbf{N N}{ }^{\mathrm{Me} 2} \mathbf{C}^{\mathrm{iPr} 2} \mathbf{O}\right\} \mathbf{Y}\left(\mathrm{CH}_{2} \mathrm{SiMe}_{3}\right)(\mathrm{THF})$ (1-Y). NMR-scale Protocol $A$. In the glove box, a J-

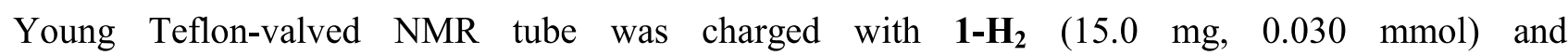
$\mathrm{Y}\left(\mathrm{CH}_{2} \mathrm{SiMe}_{3}\right)_{3}(\mathrm{THF})_{2}(15.0 \mathrm{mg}, 0.031 \mathrm{mmol})$. To this mixture, $\mathrm{C}_{6} \mathrm{D}_{6}(c a .0 .6 \mathrm{~mL})$ was vacuum- 
transferred in and the tube was shaken for $15 \mathrm{~min}$ at room temperature. ${ }^{1} \mathrm{H}$ NMR spectroscopy indicated that 1-Y formed quantitatively.

Preparative-scale Protocol B. Using a procedure similar to that described above for 1-Sc, pure 1-Y (420 mg, 86\%) was obtained from 1-H $(300 \mathrm{mg}, 0.591 \mathrm{mmol})$ and $\mathrm{Y}\left(\mathrm{CH}_{2} \mathrm{SiMe}_{3}\right)_{3}(\mathrm{THF})_{2}(292.3$ $\mathrm{mg}, 0.591 \mathrm{mmol})$ in toluene $(5 \mathrm{~mL}) .{ }^{1} \mathrm{H}$ NMR $\left(400 \mathrm{MHz}, \mathrm{C}_{6} \mathrm{D}_{6}, 298 \mathrm{~K}\right): \delta 7.25-6.80(\mathrm{~m}, 7 \mathrm{H}, \mathrm{Ar}), 6.75$ $\left(\mathrm{t},{ }^{3} J=8.0,1 \mathrm{H}, p\right.$-Py), $6.30\left(\mathrm{~d},{ }^{4} J=2.1,1 \mathrm{H}, \mathrm{Ar}\right), 5.98\left(\mathrm{~d},{ }^{2} J=13.7,1 \mathrm{H}, \mathrm{CHH}\right), 5.29\left(\mathrm{~d},{ }^{3} J=8.0,1 \mathrm{H}\right.$, $m$-Py), 5.03 (d, ${ }^{3} J=8.0,1 \mathrm{H}, m$-Py), 3.98 (3, 2H, $\left.\mathrm{CH} H+\mathrm{CH}\left(\mathrm{CH}_{3}\right)_{2}\right), 3.80$ (br m, 4H, THF), 2.69 (hept, $\left.{ }^{3} J=6.8,1 \mathrm{H}, \mathrm{CH}\left(\mathrm{CH}_{3}\right)_{2}\right), 2.46\left(\mathrm{~s}, 3 \mathrm{H},\left(\mathrm{CH}_{3}\right)_{2} \mathrm{C}_{6} \mathrm{H}_{3} \mathrm{~N}\right), 2.37\left(\mathrm{~s}, 3 \mathrm{H},\left(\mathrm{CH}_{3}\right)_{2} \mathrm{C}_{6} \mathrm{H}_{3} \mathrm{~N}\right), 2.14(\mathrm{~s}, 3 \mathrm{H}$, $\left.\left(\mathrm{CH}_{3}\right)_{2} \mathrm{C}_{6} \mathrm{H}_{3} \mathrm{~N}\right), 1.55\left(\mathrm{~s}, 3 \mathrm{H},\left(\mathrm{CH}_{3}\right)_{2} \mathrm{C}_{6} \mathrm{H}_{3} \mathrm{~N}\right), 1.49\left(\mathrm{~d},{ }^{3} \mathrm{~J}=6.8,3 \mathrm{H},\left(\mathrm{CH}_{3}\right)_{2} \mathrm{CH}\right), 1.40\left(\mathrm{~d},{ }^{3} \mathrm{~J}=6.8,3 \mathrm{H}\right.$, $\left.\left(\mathrm{CH}_{3}\right)_{2} \mathrm{CH}\right), 1.28$ (br m, 4H, THF), $1.13\left(\mathrm{~m}, 6 \mathrm{H},\left(\mathrm{CH}_{3}\right)_{2} \mathrm{CH}\right), 0.32$ (s, 9H, SiMe $),-0.44$ (br d, ${ }^{2} J=11.0$, $1 \mathrm{H}, \mathrm{CHHSiMe}$ ) $,-0.62\left(\mathrm{br} \mathrm{d},{ }^{2} J=11.0,1 \mathrm{H}, \mathrm{CHHSiMe} 3\right) .{ }^{13} \mathrm{C}\left\{{ }^{1} \mathrm{H}\right\} \mathrm{NMR}\left(125 \mathrm{MHz}, \mathrm{C}_{6} \mathrm{D}_{6}, 298 \mathrm{~K}\right): \delta$

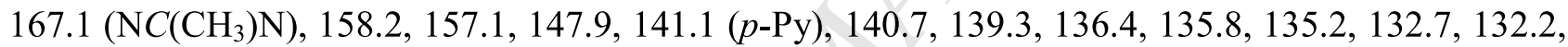
128.0, 127.2, 125.9, 123.3, 122.5, 95.1 (m-Py), 91.1 (m-Py), $69.6\left(\alpha-C \mathrm{H}_{2}\right.$ THF), $49.4\left(C \mathrm{H}_{2}\right), 33.7$ $\left(\mathrm{CH}\left(\mathrm{CH}_{3}\right)_{2}\right), 26.9\left(\mathrm{CH}\left(\mathrm{CH}_{3}\right)_{2}\right), 25.9\left(\mathrm{~d},{ }^{1} \mathrm{~J}_{\mathrm{Y}-\mathrm{C}}=41.4, \mathrm{CH}_{2} \mathrm{SiMe}_{3}\right), 25.7\left(\beta-\mathrm{CH}_{2} \mathrm{THF}\right), 24.9\left(\mathrm{CH}\left(\mathrm{CH}_{3}\right)_{2}\right)$, $24.6\left(\mathrm{CH}\left(\mathrm{CH}_{3}\right)_{2}\right), 24.0\left(\mathrm{CH}\left(\mathrm{CH}_{3}\right)_{2}\right), 22.7\left(\mathrm{CH}\left(\mathrm{CH}_{3}\right)_{2}\right), 19.6\left(\left(\mathrm{CH}_{3}\right)_{2} \mathrm{C}_{6} \mathrm{H}_{3} \mathrm{~N}\right), 19.5\left(\left(\mathrm{CH}_{3}\right)_{2} \mathrm{C}_{6} \mathrm{H}_{3} \mathrm{~N}\right), 17.9$ $\left(\left(\mathrm{CH}_{3}\right)_{2} \mathrm{C}_{6} \mathrm{H}_{3} \mathrm{~N}\right), 17.8\left(\left(\mathrm{CH}_{3}\right)_{2} \mathrm{C}_{6} \mathrm{H}_{3} \mathrm{~N}\right), 4.2(\mathrm{SiMe})$. Anal. Calcd for $\mathrm{C}_{42} \mathrm{H}_{58} \mathrm{~N}_{3} \mathrm{O}_{2} \mathrm{YSi}: \mathrm{C}, 66.91 ; \mathrm{H}$, 7.75; N, 5.57. Found: C, 70.12; H, 7.98; N, 5.75.

General Procedure for Polymerization of rac-Lactide. In a typical experiment (Table 1, entry 4), in the glovebox, a Schlenk flask was charged with complex 1-Sc $(12.0 \mathrm{mg}, 16.0 \mu \mathrm{mol})$. Outside the glovebox and under argon, complex 1-Sc was dissolved in toluene $(1.69 \mathrm{~mL})$ and $i \operatorname{PrOH}(8.5 \mu \mathrm{L}$ of a 2.0 $\mathrm{M}$ solution in toluene, $16.9 \mu \mathrm{mol}, 1$ equiv vs. $[\mathrm{M}]_{0}$ ) was added. The reaction mixture was immediately stirred with a magnetic stirring bar at $25{ }^{\circ} \mathrm{C}$ for $16 \mathrm{~h}$. The reaction was quenched with water $(1 \mathrm{~mL}$ of a $10 \mathrm{~mol} \%$ solution in THF). Volatiles were evaporated and the conversion was determined by ${ }^{1} \mathrm{H}$ NMR spectroscopy from the crude material. Monomer (LA) conversions were 
calculated from ${ }^{1} \mathrm{H}$ NMR spectra of the crude reaction mixtures in $\mathrm{CDCl}_{3}$, from the integration (Int.)

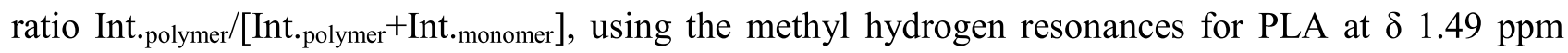
and for LA at $\delta 1.16 \mathrm{ppm}$. The polymer was dissolved in THF (5 mL) and reprecipitated with pentane (ca. $100 \mathrm{~mL}$ ). The polymer was filtered and dried under vacuum till constant weight. The microstructure of the PLA was determined by homodecoupling ${ }^{1} \mathrm{H}$ NMR spectroscopy experiment at $25{ }^{\circ} \mathrm{C}$ in $\mathrm{CDCl}_{3}$ on a Bruker AC-500 spectrometer.

Crystal Structure Determination of 1-H $\mathbf{H}_{2}$ and 2-Sc. Diffraction data were collected at 150(2) $\mathrm{K}$ using a Bruker APEX CCD diffractometer with graphite-monochromatized Mo-K $\alpha$ radiation $(\lambda=$ $0.71073 \AA$ Á). The crystal structures were solved by direct methods, remaining atoms were located from difference Fourier synthesis followed by full-matrix least-squares refinement based on F2 (programs SIR97 and SHELXL-97). ${ }^{17}$ Many hydrogen atoms could be located from the Fourier difference analysis. Other hydrogen atoms were placed at calculated positions and forced to ride on the attached atom. The hydrogen atom positions were calculated but not refined. All non-hydrogen atoms were refined with anisotropic displacement parameters. For 2-Sc, the contribution of the disordered solvents to the calculated structure factors was estimated following the BYPASS algorithm, ${ }^{18}$ implemented as the SQUEEZE option in PLATON. ${ }^{19}$ Crystal data and details of data collection and structure refinement for the different compounds are given in Table S1. Detailed crystallographic data (excluding structure factors) are available as Supporting Information, as cif files.

\section{References}

For leading reviews on the synthesis of metal phenoxides, see: (a) Bochkarev, M. N.; Zakharov,

L. N.; Kalinina G. S. Organoderivatives of rare earth elements. Nauka, Moscow, 1989. (b) 
Bradley, D. C.; Mehrotra, R. C.; Rothwell, I. P.; Singh, A. Alkoxo and Aryloxo Derivatives of Metals. Academic Press, New York, 2001.

For selected recent reviews on the synthesis of metal amidinates, see: (a) Trifonov, A. A. Coord. Chem. Rev. 2010, 254, 1327-1347. (b) Edelmann, F. T. Chem. Soc. Rev. 2009, 38, 2253-2268.

(a) Aubrecht, K. B.; Chang, K.; Hillmyer, M. A.; Tolman, W. B. J. Polym. Sci. Polym. Chem. 2001, 39, 284-293. (b) Giesbrecht, G. R.; Whitener, G. D.; Arnold, J. J. Chem., Dalton Trans. 2001, 923-927. (c) Wang, J.; Yao, Y.; Shen, Q. Inorg. Chem. 2009, 48, 744-751. (c) Qin, D; Han, F; Yao, Y; Zhang, Y; Shen, Q. Dalton Trans. 2009, 5535-5541.

(a) Stewart, P. J.; Blake, A. J.; Mountford, P. Organometallics 1998, 17, 3271-3281. (b) Haas, I.; Kretschmer, W.; Kempe, R. PCT WO2014/139861 A1.

Haas, I.; Dietel, T.; Press, K.; Kol, M.; Kempe, R. Chem. Eur. J. 2013, 19, 14254-14262.

(a) Kirillov, E.; Roisnel, T.; Carpentier, J.-F. Organometallics 2012, 31, 3228-3240. (a) Sinenkov, M.; Kirillov, E.; Roisnel, T.; Fukin, G.; Trifonov, A.; Carpentier, J.-F. Organometallics 2011, 30, 5509-5523.

(a) Radkov, V.; Dorcet, V.; Carpentier, J.-F.; Trifonov, A.; Kirillov, E. Organometallics 2013, 32, 1517-1527. (b) Radkov, V.; Roisnel, T.; Trifonov, A.; Carpentier, J.-F.; Kirillov, E. Eur. J. Inorg. Chem. 2014, 25, 4168-4178. (c) Radkov, V.; Roisnel, T.; Trifonov, A.; Carpentier, J.-F.; Kirillov, E. J. Am. Chem. Soc. 2016, 138, 4350-4353.

The following numbering scheme is used:<smiles>Cc1cccc(C)c1Nc1cccc(N(Cc2cc(C(C)C)cc(C(C)C)c2O)c2c(C)cccc2C)n1</smiles> 
Ligand redistribution reactions resulting in formation of bis(ligand) products have been described for alkyl and iodo complexes of group 3 metals incorporating amidinate, amido and related ligands; see: (a) Hultzsch, K. C.; Voth, P.; Beckerle, K.; Spaniol, T. P.; Okuda, J. Organometallics 2000, 19, 228-243. (b) Bambirra, S.; Brandsma, M. J. R.; Brussee, E. A. C.; Meetsma, A.; Hessen, B.; Teuben, J. H. Organometallics 2000, 19, 3197-3204. (c) Bambirra, S.; Van Leusen, D.; Tazelaar, C. G. J.; Meetsma, A.; Hessen, B.; Teuben, J. H. Organometallics 2007, 26, 1014-1023. (d) Jian, Z.; Cui, D. Dalton Trans. 2012, 41, 2367-2373. (e) Marshall, G.; Wooles, A. J.; Mills, D. P.; Lewis, W.; Blake, A. J.; Liddle, S. T. Inorganics 2013, 1, 46-69.

Zwitterionic group 3 metal complexes incorporating two dianionic bis(phenolate)amido ligands have been reported; see: (a) Clark, L.; Cushion, M. G.; Dyer, H. E.; Schwarz, A. D.; Duchateau, R.; Mountford, P. Chem. Commun. 2010, 46, 271-275. (b) Dyer, H. E.; Huijser, S.; Schwarz, A. D.; Wang, C.; Duchateau, R.; Mountford, P. Dalton Trans. 2008, 32-35.

(a) Hitchcock, P. B.; Lappert, M. F.; Singh, A. J. Chem. Soc. Chem. Commun. 1983, 1499-1501.

(b) Chapurina, Y.; Klitzke, J.; Casagrande Jr, O.; Awada, M.; Dorcet, V.; Kirillov, E.; Carpentier, J.-F. Dalton Trans. 2014, 43, 14322-14333.

(a) Liu, X.; Shang, X.; Tang, T.; Hu, N.; Pei, F.; Cui, D.; Chen, X.; Jing, X. Organometallics 2007, 26, 2747. (b) Normand, M.; Kirillov, E.; Roisnel, T.; Carpentier, J.-F. Organometallics 2012, 31, 1448-14557.

Cotton , F. A.; Daniels, L. M.; Lei, P.; Murillo, C. A.; Wang, X. Inorg. Chem.2001, 40, 27782784.

(a) Lappert, M. F.; Pearce, R. J. J. Chem. Soc., Chem. Commun.1973, 126-127. (b) Schumann, H.; Freckmann, D. M.; Dechert, S. Z. Z. Anorg. Allg. Chem.2002, 628, 2422-2426. Ma, H.; Okuda, J. Macromolecules 2005, 38, 2665. 
17

(a) Sheldrick, G. M. SHELXS-97, Program for the Determination of Crystal Structures, University of Goettingen (Germany), 1997; (b) Sheldrick, G. M. SHELXL-97, Program for the Refinement of Crystal Structures, University of Göttingen (Germany), 1997. (c) Sheldrick, G. M. Acta. Cryst. 2008, A64, 112.

18 Sluis, P. v. d.; Spek, A. L. Acta Cryst. 1990, A46, 194-201.

19 Spek, A. L. J. Appl. Cryst. 2003, 36, 7-13. 


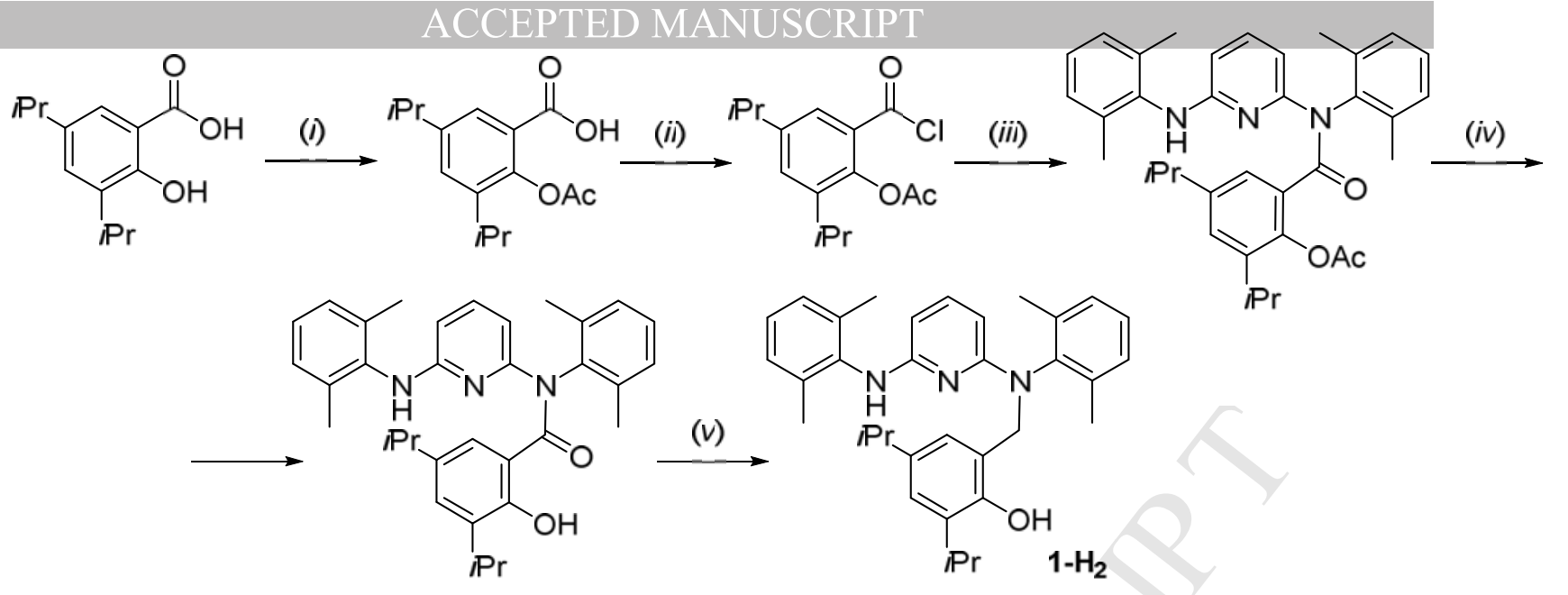

Scheme 2. Synthesis of the hybrid amidine-phenolate proligand $\left[\mathrm{N}^{\mathrm{Me} 2} \mathrm{NN}^{\mathrm{Me} 2} \mathrm{C}^{i \mathrm{Pr} 2} \mathrm{O}\right] \mathrm{H}_{2}\left(\mathbf{1}-\mathbf{H}_{\mathbf{2}}\right)$.

Conditions: (i) acetic anhydride (6 equiv), $\mathrm{H}_{2} \mathrm{SO}_{4}$ (cat), $160{ }^{\circ} \mathrm{C}, 15$ min, $63 \%$ yield; (ii) $\mathrm{SOCl}_{2}$ (20 equiv), THF, $0{ }^{\circ} \mathrm{C}-\mathrm{RT}$, overnight, $>99 \%$ yield; (iii) $\mathrm{Et}_{3} \mathrm{~N}$ (3 equiv), xylenes, $190{ }^{\circ} \mathrm{C}$, overnight, 54\% yield; (iv) $\mathrm{NaOH}(1 \mathrm{M})$, THF- $\mathrm{H}_{2} \mathrm{O}$, RT, 5 h, 61\% yield; (v) $\mathrm{BH}_{3} \cdot \mathrm{THF}$ (5 equiv), THF, $0-50{ }^{\circ} \mathrm{C}, 1 \mathrm{~h}, 30 \%$ yield.

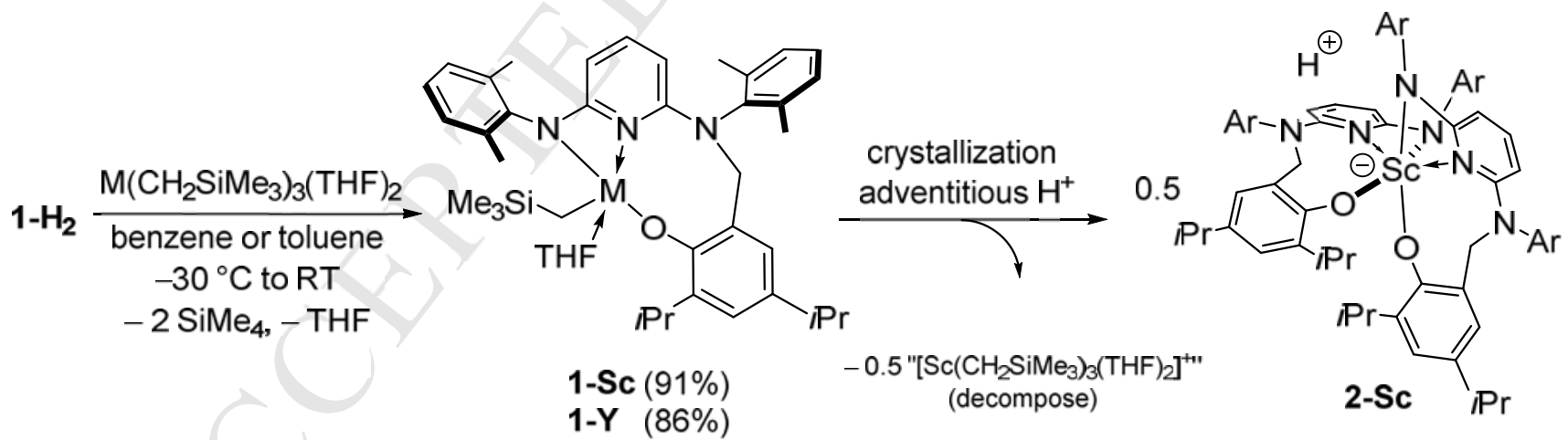

Scheme 3. Synthesis of complexes 1-Sc, 1-Y and isolation of 2-Sc. 